\title{
Beryllium Content of Volcanic Rocks
}

By DANIEL R. SHAWE and STANLEY BERNOLD

CONTRIBUTIONS TO GEOCHEMISTRY

GE OLOGICAL S URVEY B U L E T IN 1214-C

An evaluation of the relation of beryllium content to silica, water, and fluorine content and to geographic location of 1,179 samples of volcanic rocks, mostly from the Western United States

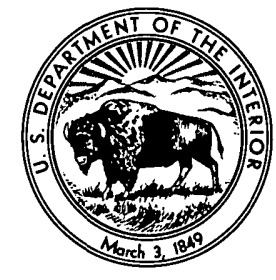


UNITED STATES DEPARTMENT OF THE INTERIOR

STEWART L. UDALL, Secretary

GEOLOGICAL SURVEY

William T. Pecora, Director 


\section{CONTENTS}

\begin{tabular}{|c|c|}
\hline \multirow{2}{*}{ Abstract } & Page \\
\hline & $\mathrm{C} 1$ \\
\hline Introduction, & 1 \\
\hline Previous work & 2 \\
\hline Analytical data & 3 \\
\hline on of beryllium with silica content & 3 \\
\hline beryllium with water content & 6 \\
\hline veryllium with fluorine content & 7 \\
\hline ns among silica, water, and fluorine & 8 \\
\hline Geographic distribution of beryllium $\ldots \ldots$ & 9 \\
\hline & 10 \\
\hline & 11 \\
\hline
\end{tabular}

\section{ILLUSTRATIONS}

[Plates are in pocket]

Plates 1-3. Scatter diagrams showing relation of beryllium to:

1. Silica in volcanic rocks.

2. Total water in volcanic rocks.

3. Fluorine in volcanic rocks.

4-6. Scatter diagrams showing:

4. Relation of total water to silica in volcanic rocks.

5. Relation of fluorine to silica in volcanic rocks.

6. Relation of fluorine to total water in volcanic rocks.

7. Map of western conterminous United States showing location and relative beryllium content of chemically analyzed volcanic rocks.

\section{TABLES}

TABLE 1. Correlation of beryllium with silica in saturated and oversaturated volcanic rocks. ....................................

2. Beryllium and silica content of seven undersaturated volcanic rocks. . . . . . .

3. Correlation of beryllium with silica in three c̀lasses of volcanic rocks . . . . . . . .

4. Correlation of beryllium with total water in saturated and oversaturated volcanic rocks.

5. Correlation of beryllium with fluorine in saturated and oversaturated volcanic rocks..................................

6. Beryllium content of volcanic rocks from selected geographic arèas. 


\title{
CONTRIBUTIONS TO GEOCHEMISTRY
}

\section{BERYLLIUM CONTENT OF VOLGANIG ROGKS}

\author{
By Daniel R. Shawe and Stanley Bernold
}

\begin{abstract}
Spectrographic and chemical analysis of 1,172 saturated and oversaturated volcanic rocks, including tuffs, flow rocks, and glasses, bring out several possibly significant relations between the beryllium content and the content of silica, water, and fluorine. The data confirm the provincial distribution of volcanic rocks that are high in beryllium and thus serve to identify areas favorable for exploration for beryllium deposits.

The analyses indicate that beryllium content, averaging 2.3 parts per million in all rocks, has a marked tendency to increase as silica content increases. Volcanic tuffs contain, on the average, less beryllium than do flow rocks and glasses of similar silica content, and they show a constant increase of beryllium with silica. Flow rocks and glasses, however, show an increase of beryllium to a silica content of $\mathbf{7 5}$ percent, and an appreciable decrease of beryllium with higher silica content.

Analyses of a few undersaturated (alkali-rich) volcanic rocks suggest that such rocks contain an anomalously high beryllium content.

Beryllium content tends to increase with the water content of volcanic rocks up to a point, although it is low in rocks of highest water content. Among tuffs, beryllium and water have a positive correlation; and among flow rocks, a negative correlation. Among glassy volcanics, beryllium increases with water to a water content of 4 percent, and decreases with higher water content.

Beryllium has a straightforward positive correlation with fluorine in tuffs, flow rocks, and glasses.

Volcanic rocks high in beryllium are especially concentrated in western Utah, southern Idaho, and northeastern Nevada. Sparse data indicate a second broad province of anomalously high beryllium contents in central Colorado, western New Mexico, western Texas, and southeastern Arizona.
\end{abstract}

\section{INTRODUCTION}

The distribution of trace amounts of beryllium in volcanic rocks is being studied as part of a program by the U.S. Geological Survey to evaluate the potential resources of beryllium in volcanic and associated rocks in the Western United States. The study was undertaken 
because potentially economic deposits of beryllium are known to occur in silicic volcanic rocks.

For this report, analytical data on 1,179 samples, compiled from the files of the Survey, have been examined to ascertain the relation between beryllium content and the content of silica, water, and fluorine. Study of the geographic distribution of the samples high in beryllium seems to support published evidence for the occurrence of beryllium metallogenic provinces.

The samples are mostly unaltered volcanic rocks. Many rocks of one large group, namely about 250 tuffs collected at the Nevada Test Site in southern Nevada, possibly should be considered as altered rocks because they contain unusually large amounts of zeolites and water (both + and - ). The tuffs are included in this summary, however, as any possible bias introduced by these rocks has not been evaluated. Complete chemical analysis for major elements and quantitative or semiquantitative spectrographic analysis for beryllium and other trace elements are available for each of the rocks included in this study. These analyses were performed during 1950-63 in the Washington and Denver laboratories of the Survey.

This is a preliminary report. Work is continuing on the correlation and relationship of beryllium with the major oxides and minor elements and on other aspects of its distribution in volcanic rocks.

Most samples were collected from the western conterminous United States (85 percent), Hawaii ( 7 percent), and Alaska (4 percent), though rocks from the Eastern United States (11/2 percent) and many other parts of the world (21/2 percent) are represented in this compilation. Virtually all the analyzed rocks belong to the saturated and oversaturated basalt-andesite-rhyolite kindred.

\section{PREVIOUS WORK}

Published data on the beryllium content of volcanic rocks are meager. No doubt this sparsity is due to the low concentration of beryllium in most of these rocks-below the limit of detection of many early analytical techniques. Warner and others (1959) summarized the earlier literature, presented several new analyses, and concluded that "analyses of extrusive rocks are few, but those available do not differ noticeably in $\mathrm{BeO}$ content from the average for the corresponding intrusive rocks" (p. 24). These averages were given by Warner and others (1959 p. 23$)$; the "Be(ppm)" column was added by us:

\section{Rock type}

Average igneous rock

Feldspathoidal rocks

Granitic rocks.

Syenitic rocks

Intermediate rocks

Mafic and ultramafic rocks

$\begin{array}{cc}\text { BeO (percent) } & \text { Be (ppm) } \\ 0.001 & 3 \\ .0025 & 8 \\ .002 & 6 \\ .001 & 3 \\ .0007 & 2 \\ .0001 & .3\end{array}$


Beus (1956, p. 514) suggested an average beryllium content of 0.3 ppm (parts per million) for 10 basalt samples and $6 \mathrm{ppm}$ for 20 acid extrusive samples from U.S.S.R.

Pinus (1959) summarized data on the beryllium content of Cambrian and Devonian extrusives from Tuva, Siberia. He found that the beryllium content of most of the lavas was below the limit of detection. The beryllium content exceeded $10 \mathrm{ppm}$ in only a very few felsic volcanics.

Coats and others (1962) determined the beryllium content of more than 180 silicic volcanic rocks from the Cordilleran region of the United States. These rocks ranged from 0 to $20 \mathrm{ppm}$ beryllium, with a median value of $3.6 \mathrm{ppm}$. The study also suggested a nonrandom regional distribution of beryllium in the volcanics of the Western States.

Shawe and Bernold (1964, table 1) found the following average beryllium values:

\begin{tabular}{|c|c|c|c|}
\hline & \multicolumn{3}{|c|}{ Beryllium content $\underset{\text { of }}{(p a m p l e s}$ and, in parentheses, number } \\
\hline & $\begin{array}{c}\text { Mafic } \\
<1 \quad(86)\end{array}$ & 4. $1^{\text {Silicic }}(81)$ & $\begin{array}{c}\text { Alkalic } \\
4.7(17)\end{array}$ \\
\hline [ypabyssal_... & $0(10)$ & 6. $8(15)$ & $9.6(11)$ \\
\hline Plutonic & $<1(56)$ & 8. $2(124)$ & $13.8(22)$ \\
\hline
\end{tabular}

\section{ANALYTICAL DATA}

The major elements in each sample were determined by standard chémical analysis or by rapid rock analysis (Shapiro and Brannock, 1956). About 65 percent of the samples were analyzed by the standard chemical technique, and 35 percent, by the rapid rock method. The tables and diagrams in this report present analytical data recalculated on a water-free basis.

Beryllium values were determined spectrographically. About 500 samples were analyzed by quantitative spectrography; the trace element values so determined are considered accurate to within \pm 15 percent. The other samples, analyzed semiquantitatively, were generally reported in percent to the nearest number in the series 1.0, 0.7, 0.5, $0.3,0.2,0.15,0.1$, and so on. These values are approximate midpoints of brackets on a geometric scale. Any single determination will be in the correct bracket about 30 percent of the time, and in the correct bracket or one of the two neighboring brackets about 80 percent of the time.

\section{CORRELATION OF BERYLLIUM WITH SILICA CONTENT}

Beryllium content shows a marked tendency to increase with an increase of silica in saturated and oversaturated volcanic rocks, but it levels off or even decreases in rocks containing more than about 75 percent silicia. In table 1, ranges and averages of beryllium content are given for 1,172 analyses, subdivided into groups with increments 
of 2 percent silica. The silica value in each analysis was adjusted by recalculating to 100 percent without water. Semiquantitative spectrographic detection of beryllium generally has a lower limit of $1 \mathrm{ppm}$; any lower beryllium content is indicated in reports of analyses as $0 \mathrm{ppm}$. The averages for the low-silica, beryllium-poor rocks, which are stated in tenths of a part per million, are imprecise and are best regarded as indicating only a trend; strictly, they should be given as "less than 1 ppm beryllium."

TABLE 1.-Correlation of beryllium with silica in saturated and oversaturated volaanic rocks

\begin{tabular}{|c|c|c|c|}
\hline \multirow{2}{*}{ Number of samples } & \multirow{2}{*}{$\begin{array}{c}\mathrm{SiO}_{2} \text { range } \\
\text { (weight percent) }\end{array}$} & \multicolumn{2}{|c|}{ Beryllium content (ppm) } \\
\hline & & Range & Average \\
\hline $\begin{array}{r}25 \\
86 \\
91 \\
74 \\
375 \\
20\end{array}$ & $\begin{array}{l}<46.00 \\
\text { 46. } 00-47.99 \\
\text { 48. } 00-49.99 \\
\text { 50. } 00-51.99 \\
\text { 52. } 00-53.99 \\
54.00-55.99 \\
\text { 56. } 00-57.99 \\
\text { 58. } 00-59.99 \\
\text { 60. } 00-61.99 \\
\text { 62. } 00-63.99 \\
\text { 64. } 00-65.99 \\
\text { 66. } 00-67.99 \\
\text { 68. } 00-69.99 \\
\text { 70. } 00-71.99 \\
\text { 72. } 00-73.99 \\
74.00-75.99 \\
76.00-77.99 \\
>78.00\end{array}$ & $\begin{array}{l}0 \\
0-3 \\
0-2 \\
0-2 \\
0-1.5 \\
0-1.5 \\
0-5 \\
0-5 \\
0-5 \\
0-8 \\
0-5 \\
0-9 \\
0-5 \\
0-6 \\
0-20 \\
0-36 \\
0-30 \\
0-7\end{array}$ & $\begin{array}{l}0.0 \\
.1 \\
.1 \\
.1 \\
.1 \\
.4 \\
.7 \\
.7 \\
.9 \\
.9 \\
1.4 \\
1.2 \\
1.5 \\
2.0 \\
3.2 \\
4.6 \\
4.7 \\
4.0\end{array}$ \\
\hline Summary 1,172 & 39. 2-88. 7 & $0-36$ & 2. 3 \\
\hline
\end{tabular}

As table 1 shows, the 1,172 volcanic rocks averaged $2.3 \mathrm{ppm}$ beryllium. Of these, 379 rocks contained less than 60.00 percent silica (mafic) and averaged $0.2 \mathrm{ppm}$ beryllium, and 793 rocks contained 60.00 percent or more silica (silicic) and averaged $3.3 \mathrm{ppm}$ beryllium.

Of the rocks that contained less than 60.00 percent silica (table 1 ), only 13 percent had detectable beryllium. Notably, several trachybasalts are among these. The trachybasalts may be considered borderline between saturated and undersaturated rocks.

Seven other rocks, undersaturated volcanics which do not belong to the normal basalt-andesite-rhyolite kindred and hence are not included in table 1 , have anomalously high beryllium content in relation to their silica content, as is shown in table 2 .

It is apparent even from this small sampling that undersaturated volcanic rocks do not fit the beryllium-silica pattern suggested by the 
saturated rocks. The unusually high beryllium content of undersaturated (or alkalic) rocks has been noted by many authors (Goldschmidt and Peters, 1932; Warner and others, 1959; Shawe and Bernold, 1964).

TABLE 2.-Beryllium and silica content of seven undersaturated volcanic rocks

\begin{tabular}{|c|c|c|}
\hline Rock type & $\underset{\text { (percent) }}{\mathrm{SiO}_{2}}$ & $\underset{(p p m)}{\mathrm{Be}}$ \\
\hline Phonolite._. & 37. 29 & \\
\hline Leucitite & 46. 3 & 20 \\
\hline 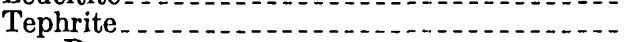 & 49.8 & 20 \\
\hline Do.. & 51.9 & 20 \\
\hline Phonolite_- & 52.18 & \\
\hline Trachyte... & 57. 21 & 5 \\
\hline D? & 60. 33 & \\
\hline
\end{tabular}

Beryllium-silica relations are different in each of three general types that make up the silicic rocks (>60.0 percent silica) in table 1: tuffs (including welded, zeolitic, and water-laid tuffs), flow rocks, and glasses (including ash, pumice, obsidian, and vitrophyre). The glassy rocks are separated from the nonglassy tuffs and flow rocks because they constitute a group of volcanics believed by some authors (such as, Coats and others, 1962, p. 963) to be significant by virtue of the likelihood that its members, having been cooled quickly, closely reflect original magma composition.

Scatter diagrams show the relation of beryllium to silica in 788 silicic rocks, including 334 tuffs (pl. $1 A$ ), 212 flow rocks (pl. 1B), and 242 glassy rocks (pl. $1 C$ ). Beryllium in tuffs tends to increase gradually from lowest to highest silica compositions. In only one sample, a beryllium-rich tuff containing nearly 77 percent silica, is the beryllium-silica relation noticeably anomalous. Beryllium in flow rocks tends to remain consistently low in the silica range of 60 to 73 percent, peaks sharply at about 75 percent silica, and is again low above 77 percent silica. A few of the flow rocks of unusually high silica content that are represented on plate $I B$, may be silicified (altered) rocks. Beryllium in glassy rocks appears to increase gradually along with silica, tending to be highest in rocks containing about 75 percent silica, and to decrease appreciably in rocks of higher silica composition. The field of one coherent group among the glasses-ash samples composed of glass shards (shown separately on pl. $1 C$ ) -mimics the field for other glassy rocks but represents rocks having a lower average beryllium content.

The beryllium-silica relation within the three groups of volcanic rocks is also summarized in table 3 , where the beryllium content of 581 rocks of the three types of volcanics is presented in groups having increments of 2 percent silica. Only rocks containing more than 70.0 
percent silica are represented, because the greatest differences in beryllium distribution among the three volcanic types lie in this range.

According to table 3, the average beryllium content of 281 tuffs is $3.4 \mathrm{ppm}$, or $0.7 \mathrm{ppm}$ less than the average for all volcanics in this silica range; that of 102 flow rocks is $4.4 \mathrm{ppm}$, or $0.3 \mathrm{ppm}$ more than the average; and that of 198 glassy volcanic rocks is $4.8 \mathrm{ppm}$ beryllium, or $0.7 \mathrm{ppm}$ greater than the average. Despite the differences in average beryllium content among the three types in the range above 70.0 percent silica, the averages of their silica content are virtually the same: 75.0 percent for tuffs, 75.4 percent for flow rocks, and 75.0 percent for glasses.

TABLE 3.-Correlation of beryllium with silica in three classes of volcanic rocks

\begin{tabular}{|c|c|c|c|c|c|c|c|c|}
\hline \multirow{2}{*}{$\underset{\text { (percent) }}{\mathrm{SiO}_{2}}$} & \multicolumn{2}{|c|}{ Tuff } & \multicolumn{2}{|c|}{ Flow rocks } & \multicolumn{2}{|c|}{ Glass } & \multicolumn{2}{|c|}{ All rocks } \\
\hline & $\begin{array}{c}\text { Number } \\
\text { of } \\
\text { samples }\end{array}$ & $\begin{array}{c}\text { Average } \\
\text { Be (ppm) }\end{array}$ & $\begin{array}{l}\text { Number } \\
\text { of } \\
\text { samples }\end{array}$ & $\begin{array}{c}\text { Average } \\
\text { Be (ppm) }\end{array}$ & $\begin{array}{c}\text { Number } \\
\text { of } \\
\text { samples }\end{array}$ & $\begin{array}{c}\text { A verage } \\
\text { Be (ppm) }\end{array}$ & $\begin{array}{c}\text { Number } \\
\text { of } \\
\text { samples }\end{array}$ & $\begin{array}{c}\text { A verage } \\
\text { Be (ppm) }\end{array}$ \\
\hline $\begin{array}{l}70.0-71.9 \\
72.0-73.9 \\
74.0-75.9 \\
76.0-77.9 \\
>78.0\end{array}$ & $\begin{array}{l}43 \\
51 \\
71 \\
97 \\
19\end{array}$ & $\begin{array}{l}2.3 \\
2.6 \\
3.3 \\
4.1 \\
4.4\end{array}$ & $\begin{array}{r}11 \\
14 \\
26 \\
43 \\
8\end{array}$ & $\begin{array}{l}1.0 \\
3.6 \\
5.7 \\
5.0 \\
3.4\end{array}$ & $\begin{array}{r}21 \\
33 \\
62 \\
78 \\
4\end{array}$ & $\begin{array}{l}2.1 \\
3.9 \\
5.6 \\
5.4 \\
3.8\end{array}$ & $\begin{array}{r}73 \\
98 \\
159 \\
220 \\
31\end{array}$ & $\begin{array}{l}2.0 \\
3.2 \\
4.6 \\
4.7 \\
4.0\end{array}$ \\
\hline$>70.0 \ldots$ & 281 & 3.4 & 102 & 4.4 & 198 & 4.8 & 581 & 4.1 \\
\hline $\begin{array}{l}\text { Difference between } \\
\text { average for class } \\
\text { and average for all } \\
\text { rocks........... }\end{array}$ & \multicolumn{2}{|c|}{-0.7} & \multicolumn{2}{|c|}{+0.3} & \multicolumn{2}{|c|}{+0.7} & \multicolumn{2}{|c|}{0.0} \\
\hline
\end{tabular}

\section{CORRELATION OF BERYLLIUM WITH WATER CONTENT}

Beryllium shows a general tendency to correlate with water content in 1,172 saturated and oversaturated volcanic rocks (table 4). In 1,118 samples containing $7 \mathrm{ppm}$ or less beryllium, the average water content increases with beryllium content. Water tends to decrease with the increase of beryllium in 54 rocks containing $8 \mathrm{ppm}$ or more beryllium.

TABLE 4.-Correlation of beryllium with total water in saturated and oversaturated volcanic rocks

\begin{tabular}{|c|c|c|c|}
\hline \multirow{2}{*}{ Number of samples } & \multirow{2}{*}{$\begin{array}{l}\text { Range in } \\
\text { beryllium } \\
\text { content } \\
(\mathrm{ppm})\end{array}$} & \multicolumn{2}{|c|}{ Water content (percent) } \\
\hline & & A verage & Range \\
\hline $\begin{array}{l}492 \\
227 \\
265 \\
134 \\
36 \\
18\end{array}$ & $\begin{array}{r}<1 \\
1-2 \\
3-4 \\
5-7 \\
8-13 \\
>14\end{array}$ & $\begin{array}{l}\text { 1. } 8 \\
\text { 3. } 4 \\
\text { 4. } 7 \\
\text { 4. } 7 \\
\text { 3. } 7 \\
2.2\end{array}$ & $\begin{array}{l}0.0-11.5 \\
0.1-11.2 \\
0.1-19.0 \\
0.1-19.0 \\
0.1-12.8 \\
0.1-8.7\end{array}$ \\
\hline Summary 1,172 & $\ldots$ & 3.2 & -- \\
\hline
\end{tabular}


The relation of beryllium to water within the three volcanic types appears to be considerably different. Scatter diagrams comparing beryllium content to total water in 788 silicic rocks making up the groups of tuffs, flow rocks, and glasses are presented on plate 2. Among tuffs, beryllium tends to increase only slightly with water content. In the group of flow rocks, beryllium reaches highest concentrations in rocks of lowest water content but is generally low in rocks of high water content. Among volcanic glasses the beryllium-water relation is more erratic, and beryllium tends to be most abundant in rocks containing about 4 percent total water. Within the subgroup of -volcanic ash samples, distinguished from other glassy rocks on plate $2 C$, beryllium tends to increase along with water up to a water content of about 4 percent; it drops noticeably in rocks having higher water content.

\section{CORRELATION OF BERYLLIUM WITH FLUORINE CONTENT}

The beryllium content of 473 saturated and oversaturated volcanic rocks tends to increase with the fluorine content (table 5). Not all of the 1.172 rocks considered in this study were analyzed for fluorine content, but those that were so analyzed are represented in table 5 and include both mafic and silicic rocks.

The beryllium-fluorine relations within the three rock types-tuff, flow rock, and glass-are shown diagrammatically on plate 3. Tuffs show a slight tendency, and flow rocks and glasses a more pronounced tendency, for beryllium to increase along with fluorine.

TABLE 5.-Correlation of beryllium with fluorine in saturated and oversaturated volcanic rocks

\begin{tabular}{|c|c|c|c|}
\hline \multirow{2}{*}{ Number of samples } & \multirow{2}{*}{$\begin{array}{c}\text { Fluorine } \\
\text { (percent) }\end{array}$} & \multicolumn{2}{|c|}{ Beryllium content (ppm) } \\
\hline & & Range & A verage \\
\hline $\begin{array}{l}210 \\
1630 \\
18 \\
12\end{array}$ & $\begin{array}{l}0.00-.04 \\
.05-.09 \\
.10-.14 \\
.15-.19 \\
.20-.47\end{array}$ & $\begin{array}{l}0-7 \\
0-20 \\
0-20 \\
0-23 \\
0-36\end{array}$ & $\begin{array}{r}1.1 \\
\text { 2. } 6 \\
\text { 5. } 8 \\
7.1 \\
15\end{array}$ \\
\hline Summary 473 & $.00-.47$ & $0-36$ & 2. 9 \\
\hline
\end{tabular}

The correlation of beryllium with fluorine in glassy silicic volcanics was shown by Coats and others (1962, fig. 3) and by Griffitts and Powers (1963, fig. 5.1). The data of Griffitts and Powers indicate, however, that within a specific lithologic unit, abundance of beryllium is not related to abundance of fluorine. Their data further show that the correlation of beryllium and fluorine is perhaps better within a group of genetically related volcanics, but that the correlation is not 
obvious unless a large number of genetically unrelated rocks are compared. Griffitts and Powers suggested that the unimodal log-normal distribution of beryllium relative to fluorine, shown by the data of Coats and others (1962), results from comparison of samples from many populations (that is, genetically unrelated rocks) having different mean beryllium concentrations. This suggestion likely is applicable also to our comparisons of beryllium and fluorine in table 5 and on plate 3 .

\section{RELATIONS AMONG SILICA, WATER, AND FLUORINE}

The generally positive correlations of beryllium with silica, with total water, and with fluorine in volcanic rocks raises the question of whether or not any of the correlations (for example, beryllium with fluorine) are superficial and exist only because both beryllium and fluorine have a positive correlation with silica. Thus, the relations among silica, water, and fluorine need to be examined.

The relation of total water to silica among tuffs, flow rocks, and glasses is shown by scatter diagrams on plate 4 . In the group of 334 silicic volcanic tuffs, plotted points show a wide spread, but a general tendency exists for water to increase as silica increases. Among 212 silicic flow rocks, water content shows little if any tendency to change as silica content changes. Among 242 silicic glassy volcanic rocks, water tends to increase as silica content increases.

Possible relations between fluorine and silica within the three groups of volcanic rocks can be examined on plate 5. Among 71 silicic tuffs, fluorine content tends to decrease as silica increases, except in a fow rocks of relatively high fluorine content. In the group of 245 mafic and silicic flow rocks, fluorine appears not to be correlated with silica generally, although rocks with relatively high fluorine content display a sharp peak at about 75 percent silica. A few fairly high fluorine values are found among flow rocks having lowest silica content. Among 157 mafic and silicic glassy volcanic rocks, fluorine shows a definite tendency to correlate with silica, and it increases sharply in the highest silica compositions.

The relation of fluorine to total water within the three groups of volcanic rocks is shown by scatter diagrams on plate 6 . Among 71 silicic tuffs, fluorine shows little tendency to correlate with water. In the group of 245 mafic and silicic flow rocks, fluorine attains highest concentrations in rocks of lowest water content, and it tends to be low in rocks with relatively high water content. Among 157 mafic and silicic glassy volcanic rocks, fluorine tends to be most abundant in rocks containing about 4 percent water. This tendency is especially well shown by the group of 68 volcanic ash samples, shown by dots on plate $6 C$. 
As indicated by the comparisons just made, beryllium and fluorine are closely related in distribution, for they show similar relations to both silica and water. Generally, however, beryllium content is poorly correlated with water content.

\section{GEOGRAPHIC DISTRIBUTION OF BERYLLIUM}

Volcanic rocks from certain geographically restricted areas in the western conterminous United States contain anomalous amounts of beryllium. In table 6, the range and average beryllium content of volcanics in various localities are presented. Certain areas, such as the Jemez Mountains of New Mexico and the east-central San Juan Mountains (Creede area), Colo., have volcanic rocks with less than average content of beryllium. Other areas, such as the Nevada Test Site and the Jefferson County-Toston quadrangle area, Montana, have rocks nearly normal in beryllium. Most interesting are those localities with anomalously high beryllium, such as the Thomas Range, Utah, and the Mackay-Twin Buttes area, Idaho. Beryllium variations in silicic volcanics in many localities are plotted on a map of the western conterminous United States (pl. 7). Beryllium values are given as differences from the averages of all volcanics with similar silica content. Plate 7 shows that rocks with unusually high beryllium content are concentrated in Utah, southern Idaho, and northeastern Nevada. Furthermore, the only known large deposits of potential beryllium ore in volcanic rock lie in this province, at Spor Mountain, Utah. Coats and others (1962) also outlined this as an area of beryllium-rich silicic volcanics. They suggested the presence of another high-beryllium zone in southeastern Arizona, western New Mexico, western Texas, and central Colorado. A zone of this extent is only partly substantiated by the data on plate 7 , but our data for this region are sparse. The samples from this region taken by Coats and his coworkers are not included in our summary because they were not analyzed for major constituents. Many of those samples, however, are high in beryllium, regardless of silica content. The validity of the proposal that the region is a beryllium province is borne out by the recent discovery of a small beryllium deposit in volcanic rocks near Truth or Consequences, N. Mex. (U.S. Geol. Survey, 1964, p. A9A10). 
TABLE 6.-Beryllium content of volcanic rocks from selected geographic areas

[Relative beryllium content is the average content of specific rocks compared with the average of all volcanic rocks of similar silica composition]

\begin{tabular}{|c|c|c|c|c|}
\hline \multirow{2}{*}{ Locality } & \multirow{2}{*}{$\begin{array}{l}\text { Number of } \\
\text { samples }\end{array}$} & \multicolumn{3}{|c|}{ Beryllium content (ppm) } \\
\hline & & Range & Absolute & Relative \\
\hline $\begin{array}{l}\text { Northern Coast Range, Oreg } \\
\text { Central California } \\
\text { Funeral Peak, Calif } \\
\text { Riggins-Big Creek, Idaho } \\
\text { Murphy-Glenns Ferry-Bruneau River, Idaho } \\
\text { King Hill-Hagerman-Shoshone, Idaho } \\
\text { Mackay-Twin Buttes, Idaho } \\
\text { Pocatello-American Falls, Idaho } \\
\text { Fremont County, Idaho-Gallatin County, Mont.- } \\
\text { Yellowstone, Wyo. } \\
\text { Northern Elko County, Nev, } \\
\text { Mount Lewis-Frenchie Creek-Cortez, Nev. } \\
\text { Egan Range-Schell Creek Range, Nev } \\
\text { Beatty, Nev. } \\
\text { Nevada Test Site } \\
\text { Thomas Range, Utah, } \\
\text { Superior-Klondyke, Ariz... } \\
\text { Jefferson County-Toston quadrangle, Mont } \\
\text { Central Colorado. } \\
\text { Creede, Colo.- } \\
\text { Jemez, N. Mex. }\end{array}$ & $\begin{array}{r}22 \\
22 \\
20 \\
20 \\
27 \\
43 \\
21 \\
34 \\
35 \\
12 \\
38 \\
24 \\
17 \\
281 \\
13 \\
21 \\
26 \\
13 \\
43 \\
42\end{array}$ & $\begin{array}{l}0-1.5 \\
0 \\
0-3 \\
0-5 \\
0-6 \\
0-20 \\
0-36 \\
0-12 \\
\\
0-10 \\
0-7 \\
0-12 \\
0-3 \\
0-16 \\
0-30 \\
2-30 \\
0-4 \\
0-4 \\
0-10 \\
0-5 \\
0-9\end{array}$ & $\begin{array}{r}0.1 \\
0.9 \\
1.2 \\
2.6 \\
2.7 \\
6.8 \\
2.3 \\
\\
2.7 \\
3.8 \\
2.3 \\
2.1 \\
4.4 \\
3.2 \\
12.6 \\
1.9 \\
1.7 \\
2.3 \\
1.1 \\
2.9\end{array}$ & $\begin{array}{r}0.0 \\
-.6 \\
-.4 \\
-.4 \\
-.2 \\
+1.4 \\
+4.9 \\
-.1 \\
-.2 \\
+1.0 \\
-.6 \\
-.7 \\
+.7 \\
+.2 \\
+8.9 \\
-.6 \\
+1.0 \\
-.0 \\
-1.1\end{array}$ \\
\hline
\end{tabular}

\section{SUMMARY AND CONCLUSIONS}

A positive correlation appears to exist between beryllium content and content of silica, total water, and fluorine in all volcanic rocks. Differences in details of correlations in different groups of volcanics emphasize a distinct though perhaps slight disparity in gross chemical makeup among the volcanic types, and they also suggest the relative importance of the relations between beryllium and the other rock components considered.

Despite its general tendency for increase along with silica, beryllium tends to decrease in flow rocks and in glasses containing more than 75 percent silica, whereas it continues to increase in tuffs containing more than 75 percent silica. Tuffs as a group, however, contain distinctly less beryllium than do flow rocks and glasses. Among tuffs beryllium has a positive correlation with total water content, and in flow rocks, a negative correlation; among glassy volcanic rocks beryllium reaches a maximum in rocks containing about 4 percent water. In all three groups of volcanic rocks, beryllium shows a straightforward positive correlation with fluorine.

The similar correlations of fluorine and beryllium with both silica and total water, except in the group of tuffs, reflect the close correlation of beryllium with fluorine. The fact that beryllium-water relations among the three different volcanic types are grossly different indicates that water is not a fundamental control on beryllium distribution in volcanic rocks. Thus, the general tendency for beryllium 
to increase along with water must reflect only the general tendency of water to increase along with silica.

Obvious correlation patterns have not been demonstrated between beryllium and other rock components (such as alkalies) in saturated and oversaturated volcanic rocks; these relations are currently being studied. Apparently, undersaturated volcanic rocks (generally alkalirich) contain unusually large amounts of beryllium.

Provincial distribution of beryllium in volcanic rocks in the western conterminous United States is well established. The distribution appears not to be related to compositional differences-at least not to differences in silica content--among the rocks.

The correlations described here point out only the relative geochemical affinities of the components in question. They do not suggest genetic mechanisms by which beryllium becomes concentrated in volcanic rocks. Like the beryllium-fluorine relation discussed by Griffitts and Powers (1963) the relations shown here are comparisons of samples from many populations. In order to learn more concerning the geologic processes that concentrate beryllium in volcanic rocks, we will have to study a great many rocks from specific geologic occurrences where genetic relations among the volcanics are well known.

\section{REFERENCES CITED}

Beus, A. A., 1956, Geokhimiya berilliya [Geochemistry of beryllium] : Geokhim, no. 5, p. 75-92. English translation in Geochemistry, pub. in 1960 by Geochem. Soc., Ann Arbor, Mich., p. 511-531.

Coats, R. R., Barnett, P. R., and Conklin, N.M., 1962, Distribution of beryllium in unaltered silicic volcanic rocks of the western conterminous United States: Econ. Geology, v. 57, p. 963-968.

Goldschmidt, V. M., and Peters, C., 1932, Zur Geochemie des Berylliums: Gesell. Wiss. Göttingen, Math.-phys. Kl., Nachr., no. 4, p. 360-376.

Griffitts, W. R., and Powers, H. A., 1963, Beryllium and fluorine content of some silicic volcanic glasses from Western United States, in Short papers in geology and hydrology: U.S. Geol. Survey Prof. Paper 475-B, p. B18-B19.

Pinus, G. V., 1959, Chemical and geochemical characteristics of the Cambrian extrusives of Tuva : Geochemistry, no. 1, p. 99-111.

Shapiro, Leonard, and Brannock, W. W., 1956, Rapid analysis of silicate rocks : U.S. Geol. Survey Bull. 1036-C, p. 19-56.

Shawe, D. R., and Bernold, Stanley, 1964, Distribution of beryllium in igneous rocks, in Geological Survey research 1964: U.S. Geol. Survey Prof. Paper 501-B, p. B100-B104.

U.S. Geological Survey, 1964, Geological Survey research 1964 : U.S. Geol. Survey Prof. Paper 501-A, p. A9-A10.

Warner, L. A., Holser, W. T., Wilmarth, V. R., and Cameron, E. N., 1959, Occurrence of nonpegmatite beryllium in the United States: U.S. Geol. Survey Prof. Paper 318, 198 p. 